\title{
Tradisi Panjang Mulud Di Kesultanan Banten Lama Analisis Semiotika Roland Barthes
}

\author{
Nofia Natasari \\ UIN Syarif Hidayatullah Jakarta \\ nofianatasari@gmail.com
}

\begin{abstract}
The tradition of Panjang Mulud dates back to the time of the Old Banten Sultanate. At first, the tradition became a place for the public to feel euphoric about the gifts received from the Arab Kingdom. This tradition has the meaning of blessing and togetherness. However, at this time the tradition of Panjang Mulud underwent changes from the procession to the symbols being paraded. These changes are evidenced by the practices of power. These cultural practices occurred with the political turmoil that occurred in the Old Banten Sultanate. The shift in the period from the government structure affects the practices in the realization of the Panjang Mulud Tradition.
\end{abstract}

Keywords: Panjang Mulud Tradition, culture, semiotics, and politics.

\begin{abstract}
Abstrak
Tradisi Panjang Mulud berasal dari masa Kesultanan Banten Lama. Pada awalnya, Tradisi Panjang Mulud ini menjadi wadah rasa euforia masyarakat akan hadiah yang didapat dari Kerajaan Arab. Tradisi ini memiliki makna keberkahan dan kebersamaan. Namun, saat ini Tradisi Panjang Mulud mengalami perubahanperubahan dari prosesi hingga simbol-simbol yang diarak. Perubahan-perubahan itu dibuktikan dengan praktik-praktik kekuasaan. Praktik-praktik kebudayaan ini terjadi dengan gejolak politik yang terjadi di Kesultanan Banten Lama. Pergeseran periode dari struktur kepemerintahan mempengaruhi praktik-praktik dalam perealisasian Tradisi Panjang Mulud.
\end{abstract}

Kata kunci: Tradisi Panjang Mulud, kebudayaan, semiotika, dan politik

Permalink/DOI: http://doi.org/10.15408/dakwah.v25i1.23178

\section{PENDAHULUAN}

Keanekaragaman budaya yang ada

di Indonesia, memberikan nilai tersendiri terhadap bangsa Indonesia. Setiap budaya memiliki ciri tersendiri yang memberikan nuasa berbeda antara 
satu kebudayaan dengan budaya lainnya. Dimana ciri ini, memiliki makna tersendiri untuk budaya tersebut. Budaya-budaya yang ada di Indonesia, bukan hanya dalam konteks bahasa melainkan dalam bentuk arsitektur, kuliner, pakaian adat hingga adat istiadat yang ada di Indonesia memiliki keberagaman.

Banten adalah daerah yang tak jauh dari Jakarta. Banten merupakan provinsi di Pulau Jawa yang terletak paling barat di Pulau Jawa. Banten pernah menjadi bagian dari Provinsi Jawa Barat, namun saat ini sudah tidak lagi sebab provinsi ini menjadi wilayah pemekaran sejak tahun 2000. Selain itu jika dilihat dari sejarah penyebaran agama Islam di Indonesia, Banten merupakan salah satu daerah yang menjadi pusat penyebaran agama Islam.

Sama halnya dengan beberapa daerah yang ada di Indonesia, seperti Daerah Istimewa Yokyakarta, Surakarta, Cirebon dan daerah yang lainnya, Banten masih memberikan ruang dalam merayakan hari besar Islam salah satunya ialah perayaan Maulid Nabi. Dalam perayaan hari besar Islam di Banten terutama di lingkungan Kesultanan Banten Lama masih menjunjung tinggi, ajaran agama Islam yang dianut. Perayaan Maulid Nabi di Banten Lama dikenal dengan nama Tradisi Panjang Mulud, yang diadakan setiap tanggal 12 Rabi'ul Awal.

Tradisi Panjang Mulud yang ada di Banten sama halnya dengan tradisi sekaten yang diselenggarakan di Keraton Surakarta dan Yogyakarta, dimana keduanya sama-sama bagian dari perayaan tradisi tahunan untuk memperingati hari kelahiran Nabi Muhammad SAW. DimanaTradiri Panjang Mulud ini, memiliki nilai-nilai gotong-royong, semangat dan rasa syukur atas kelahiran baginda Nabi Muhammad SAW. Bukan hanya mensyukuri atas kelahiran baginda Nabi Muhammad SAW, namun dalam Tradisi Panjang Mulud ini kental dengan nuasa Islam yang dapat terlihat dari simbolsimbol didalamnya. Selain itu di dalam tradisi ini juga mengagungkan sang maha pencipta Allah SWT, berkat rahmat dan karuniannya Tradisi Panjang Mulud masih terjaga kelestariannya hingga saat ini.

Tradisi Panjang Mulud, dalam realisasinya sudah berjalan selama beberapa periode di Kesultanan Banten Lama. Setiap periodenya mengalami perubahan-perubahan yang mana memberikan nuasa tersendiri. Diawal prosesinya selain merayakan Mauli Nabi, Tradisi Panjang Mulud ini bagian dari media informasi kepada seluruh masyarakat terkait dengan hadiah yang diberikan oleh Kerajaan Arab kepada Raja Banten. Saat ini, dalam perayaannya terdapat unsur inovasi dan kreatifitas. Walaupun begitu, dalam realisasinya perayaan Tradisi Panjang Mulud masih mengangkat atau menjunjung tinggi nilai-nilai luhur yang ada, terutama nilai-nilai Islam yang patut untuk diteladani.

Greetz, menuturkan bahwa agama merupakan sistem simbol dan kerenanya juga sistem budaya as a culturalsystem, yang menjadi acuan manusia atau umat dalam menginterpretasikan lingkungan 
untuk memenuhi kebutuhannya. Agama dapat dipandang sebagai suatu bagian yang memberikan pencerahan atas masalah-masalah yang dihadapi dalam kehidupan ini. Dalam konteks ini masalah yang dimaksud bukan hanya masalah yang dihadapi sekarang, namun mencangkup masalah nanti (akhirat) dan masalah-masalah yang tidak tampak (dunia gaib), karena ketika berbicara soal agama maka akan ada tuntutan dan janjijanji kepada pemeluknya.

Berdasarkan penjelasan diatas, maka peneliti ini akan mengidentifikasi masalah yang berkaitan dengan makna, bentuk, hingga proses dari pelaksanaan Tradisi Panjang Mulud. Peneliti merumuskan masalah yakni "makna denotatif, konotatif, dan mitosdalam Tradisi Panjang Mulud". Dari rumusan masalah tersebut, peneliti ingin mendeskripsikan Tradisi Panjang Mulud yang ada di wilayah Kesultanan Banten Lama terkait dengan kajian semiotika Roland Barthes.

\section{Metode Penelitian}

Artikel ini disusun dengan menggunakan paradigma konstruktivis, dimana paradigma ini menekankan bahwa realitas yang ada ditengah-tengah masyarakat merupakan bagian dari kontruksi sosial. Penggunaan paradigma ini, untuk mengetahui realitas Tardisi Panjang Mulud. Dalam melihat hal ini, peneliti menggunakan pendekatan kualitatif, dimana pendekatan ini merupakan suatu pendekatan yang beroroentasi kepada gejala-gejala yang bersifat alamiah di mana dalam mencari data-data peneliti harus terjun di lapangan yang menjadi tempat penelitian. Kemudian metode yang digunakan dalam penelitian ini adalah semiotika, dimana peneliti ingin mencari makna dan menemukan apa yang sesungguhnya berada dibalik pelaksanaan Tradisi Panjang Mulud dalam kaitannya dengan struktur dan kepercayaan yang ada di tengah-tengah masyarakat.

\section{Tradisi Panjang Maulud}

Tradisi adalah tatanan keyakinan dan tata cara yang diwarisi dari masa lalu,sehingga ketika diupayakan untuk menginterpretasikan pengalaman di masa lalu,tradisi tersebut menjadi berubah. Kebiasaan yang turun-temurun dalam suatu masyarakat itu disebut tradisi(Mardimin, 1994). Tradisi Maulid Nabi adalah sebuah perayaan yang dilakukan dalam rangka memperingati hari kelahiran Nabi Muhammad SAW, sebagai pengejewatahan dan rasa cinta umat kepada Sang Nabi. Tradisi Maulid Nabi banyak dilakukan oleh umat Islam di seluruh dunia (Nadia, 2011). 
Di Indonesia, perayaan Maulid

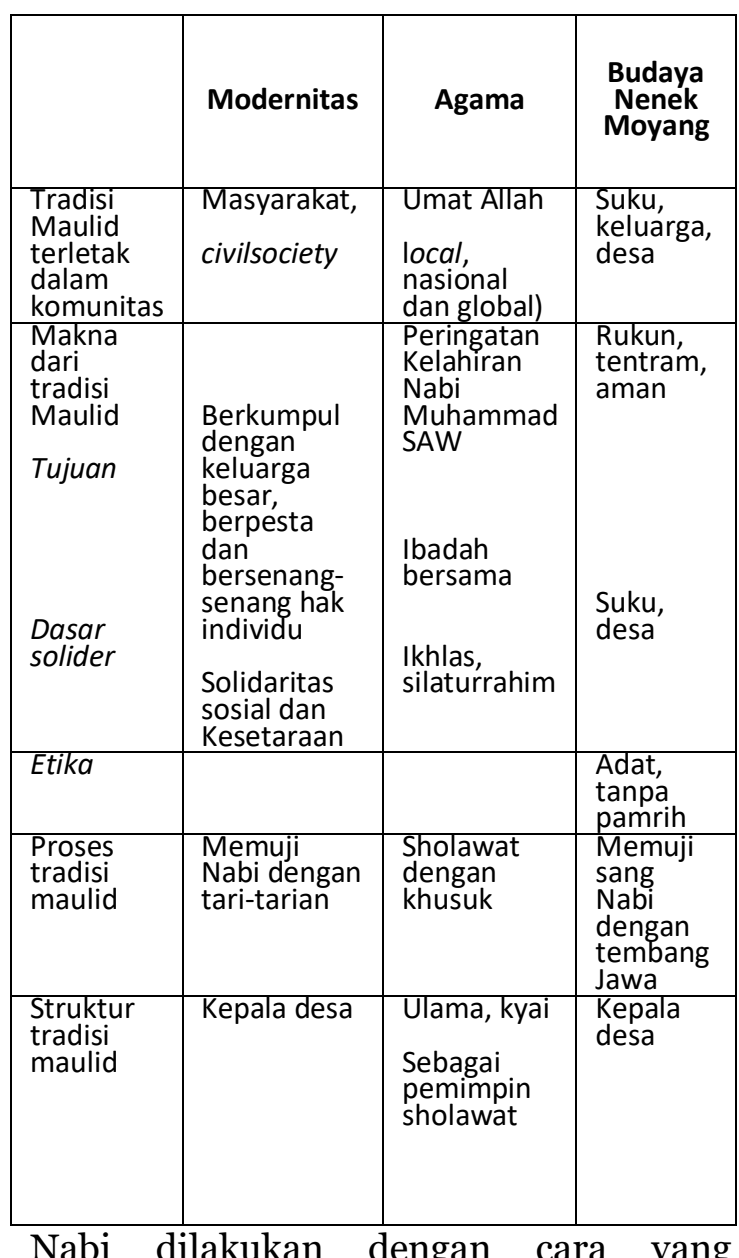

berbeda-beda sesuai dengan kultur masyarakat di setiap daerah. Kemudian terjadilah pergulatan antara agama dan tradisi bagi sebagian kalangan umat Islam, perayaan Maulid Nabi Muhammad SAW dianggap bidah dan menyebabkan bercampurnya unsurunsur syirik yang dilarang oleh agama (Nadia, 2011).Namun, kemudian peringatan hari lahir Nabi Muhammad SAW ini, berlanjut dan menjadi tradisi yang dilestarikan oleh umat Islam. Meskipun dalam perayaannya, memiliki perbedaan pendapat soal bagaimana realisasi sebenarnya dalam praktik kebudayaan. Menurut Bernard T. Adeney Ristakotta, terdapat kerangka model masyarakat Indonesia, yaitu: modernitas, agama, dan budaya nenek moyang, dimana ketiganya menyiratkan adanya satu keterkaitan dengan menggunakan jaringan makna atau bahasa yang membentuk kehidupan nyata masyarakat Indonesia. Tidak ada golongan modern, golongan agama, dan golongan budaya yang murni (Nadia, 2011). Dibawah ini, merupakan tabel Tradisi Maulid Nabi yang tebagi kedalam tiga jaringan makna:

\section{Tabel Maulid Nabi (Nadia, 2011)}

Dari tabel diatas menerangkan makna tradisi Maulid dalam tiga jaringan makna yakni, modernitas, agama dan budaya nenek moyang. Pertama adalah modernitas. Sebagai masyarakat modern yang hidup dalam dunia yang sudah dikuasai modernitas, mau tidak mau modernitas sudah menjadi bagian dari identitas dalam dirinya. Modernitas (Adeney-Risakotta, 2009) sangat memengaruhi kehidupan masyarakat baik dalam idea atau gagasan, teknologi, institusi maupun dalam aspek kehidupan sehari-hari (Nadia, 2011).

Dalam hal ini Tradisi Maulid Nabi di Kesultanan Banten Lama dalam kerangka modernitas yakni dalam Tradisi Panjang Mulud yang pada awalnya hanya mengarak hadiah yang diberikan oleh Raja Arab kepada Kerajaan Banten, kini berubah menjadi arak-arakan yang berupa makanan-makanan cepat saji seperti mie instan, kopi instan dan lain sebagainnya. Selain pada awalnya Tradisi Maulid Nabi ini sebagai rasa euforia namun untuk saat ini berubah menjadi kesan ria atau sombong, karena 
masyarakat golongan mampu maupun tidak mampu sama-sama berusaha untuk mengeluarkan dana yang semaksimal mungkin untuk menyambut tradisi ini, dan bukan lagi sebagai simbol Islam karena yang diarak bukan lagi simbolsimbol Islam melainkan simbol-simbol kehidupan (Yadi Ahyadi, Komunikasi Pribadi, 11 Juni 2015). Dalam kerangka agama, Tradisi Panjang Mulud ini jelas menemukan relevansinya karena pada saat pelaksanaannya dilakukan pada bulan Rabi'ul Awal dan simbol-simbol yang diarak mengandung unsur-unsur Islam. Dalam pelaksanaannya, inti dari tradisi Maulid ini pembacaan sholawat Nabi yang secara agama mempunyai legistimasi yang kuat bagi kaum muslim untuk melaksanakannya. Ketiga adalah budaya nenek moyang, unsurini ada dalam tradisi malam tirakatan dimana ketiganya menjadi satu kesatuan yang tidak dapat dipisahkan satu sama lain.

Semiotika Barthes merupakan pengembangan dari semiotika Saussure dengan menyelidiki hubungan antara tanda (signifier) dan petanda (signified) pada sebuah tanda (sign). Hubungan penanda dan petanda bukanlah kesamaan tapi ekuivalen (Bramantyo, 2003). Bukannya yang kemudian membawa pada yang lain tetapi hubungan yang menyatukan keduanya (Kurniawan,2001).

Roland Barthes yang juga menjadikan semiotika sebagai pendekatan utama ilmu budaya, ia juga menjelaskan maksud dari semiotika adalah untuk menerima semua sistem tanda, apapun hakekatnya dan batasnya, baik gambar, isyarat, suara musik, objek dan semua hal-hal tersebut, yang membentuk kebiasaan atau hal lain, yang bukan berupa bahasa, paling tidak adalah suatu sistem signikasi, yaitu adanya hubungan antara signifier dan signified untuk memberikan makna.

Konsep Barthes terkait dengan sintagmatik dan paradigmatik untuk menjelaskan gejala budaya. Ia memandang semua itu sebagai suatu bahasa yang memiliki sistem relasi dan oposisi. Semiotika menurut Roland Barthes, dikaitkan dengan denotasi, konotasi dan mitos. Dalam semiotika denotasi dan konotasi adalah istilah yang menggambarkan hubungan antara penanda dan signifiednya, dan perbedaan analitik dibuat antara dua jenis menandakan. Sebagian tanda-tanda setidaknya memiliki satu norma atau pemahaman sesuai dengan akal sehat makna. Makna ini disebut denotasi tanda dimana penetapannya sesuai dengan seberapa sering digunakan. Barthes meneruskan pemikiran Saussure dengan menekankan interaksi antara teks dengan pengalaman personal dan kultural penggunanya. Interaksi antara konvensi dalam teks dengan konvensi yang dialami dan diharapkan oleh penggunanya. Gagasan Barthes ini dikenal dengan Two Order ofSignification (Signifikansi Dua Tahap).

\section{Signifikansi Dua Tahap Barthes (Rahmawati dkk., 2012)}

Melalui gambar diatas, Barthes seperti dikutip Fiske menjelakansignifikansi tahap pertama merupakan hubungan antara signifier dan signifieddi dalam sebuah tanda 
terhadap realitas eksternal. Barthes menyebutnya sebagai denotasi. Konotasi adalah istilah yang digunakan Barthes untuk signifikansi tahap kedua. Hal ini menggambarkan interaksi antara tanda dengan perasaan atau emosional dari pembaca serta nilai-nilai dari kebudayaan. Pada signifikansi tahap kedua yang berkaitan dengan isi, dimana tanda berkerja melalui mitos (Sobur, 2001).

Konsep denotasi adalah makna awal atau makna utama darisebuah tanda, teks, dan sebagainnya. Menurut Barthes adalah makna yang objektif dan tetap. Tingkat Pertandaan yang menjelaskan tentang hubungan penanda dan pertanda pada realitas, menghasilkan makna eksplisit, langsung dan pasti. Tingkat signifikansi dipandang sebagai representasional dan relatif mandiri. Konsep konotasi yang

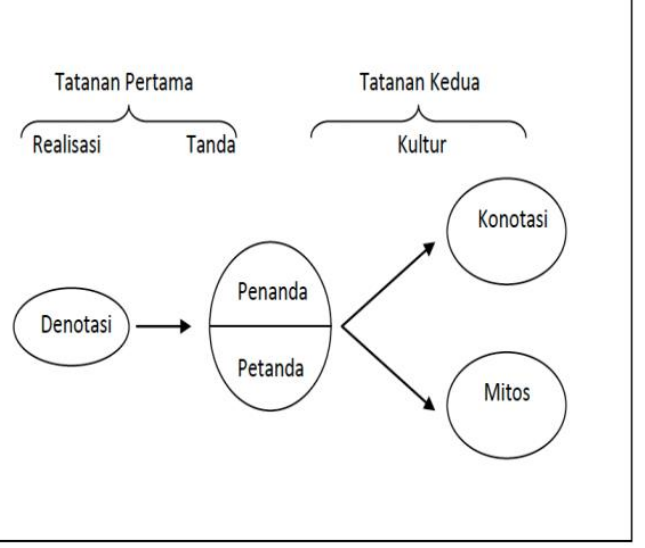
merupakan kunci semiotik dalam menganalisis budaya.

Konotasi adalah makna yang subjektif dan

bervariasi.

Tingkat pertandaan yang menjelaskan hubungan penanda dan pertanda yang di dalamnya beroperasi makna yang tidak eksplisit, tidak langsung dan tidak pasti. Perintah signifikansi mencerminkan "ekspresi" nilai-nilai, yang melekat pada tanda. Konsep mitos yang merupakan hasil penerapan konotasi dalam berbagai bidang dalam kehidupan sehari-hari. Mitos menurut Barthes adalah fakta dengan ciri-ciri: deformatif, intensional,dan motivasi. Mitos yang menandai suatu masyarakat. Mitos merupakan perkembangan dari konotasi. Konotasi yang beradadan menetap pada suatu komunitas berakhir menjadi mitos, dalam kerangka Barthes, konotasi identik dengan operasiideologi, yang disebut dengan mitos. berfungsi sebagai pengungkapan dan pembenaran bagi nilai-nilai dominan yangberlaku dalam suatu periode tertentu. Mitos menunjukkan kepada keyakinan. Mitos dapat membantu untuk memahami pengalaman dalam suatu budaya.

Seiring dengan perkembangan zaman, Tradisi Panjang Mulud juga mengalami perubahan. Awal pelaksanaan Tradisi Panjang Mulud ini menyuguhkan hasil bumi yang dimiliki oleh masyarakat Banten. Namun, saat ini karena faktor kemudahan akhirnya masyarakat tidak lagi menyuguhkan hasil bumi yang dimiliki. Produk-produk instan yang disuguhkan oleh masyarakat Banten dalam Tradisi Panjang Mulud ini bermula sejak tahun 2000-an. Penggunaan produk-produk instan ini dimaksudkan untuk mempermudah dalam penyuguhan sesaji pada Tradisi Panjang Mulud. Disaat perebutan atau pembagian Panjang, diharapkan tidak ada yang mubazir.

Seiring dengan perkembangan zaman, Tradisi Panjang Mulud ini sudah mengalami berubahan dari esensi awalnya. Perubahan-perubahan yang terjadi pada Tradisi Panjang Mulud ini berkaitan dengan Modernisasi di tengah- 
tengah masyarakat. Perubahanperubahan yang dirasakan dari proses pembuatan Panjang, dimana lebih cenderung praktis atau instan jadi Panjang tinggal dibeli. Selain itu sajian yang ada di Panjang Mulud ini tidak lagi berupa lauk-pauk yang dimasak, produkproduk instan seperti mie, kopi, pakaian, sampai kendaraan bermotor pun menghiasi sajian di Panjang Mulud. Pada titik inilah problem kebudayaan menurut GeorgSimmel sebagai "perimbangan antagonistik" antara kekuatan penciptaan dengan kebudayaan sebagai sistem (culturalsystem). Pergulatan ini berkaitan dengan manusia yang diposisikan sebagai kreator sedangkan kebudayaan terposisi sebagai sistem sosial (Arif \&Kusumaningratri, 2010).

Makna awal dari Tradisi Panjang Mulud, yaitu (Yadi Ahyadi, Komunikasi Pribadi, 11 Juni 2015).: Memberitahukan kepada masyarakat bahwa kerajaan Banten mendapatkan gelar Sultan dan hadiah. Berdasarkan Pupuh 43. Pemberian hadiah kepada kerajaan Banten dan gelar Sutan serta utusan Banten yang berangkat ke Mekah juga diberi gelar. Demang Tisnajaya mendapat gelar dan nama Haji Jayasanta dan Mas Wangsaraja menjadi gelar Haji Wangsaraja (Pudjiastuti, 2007). (2) Memohon do'a untuk segera naik haji. Bentuk dari simbol ini bisa dilihat dari Kiswah. Masyarakat percaya jika, masyarakat bisa mencium kiswah pada saatTradisi Panjang Mulud maka suatu saat nanti akan naik Haji. (3) Diberikan keberkahan, serta saling menjalin silaturahmi antar keluarga danmasyarakat. Keberkahan ini dilambangkan dari nasi dan berkat. Sedangkansilaturahmi dilambangkan dengan pembuatan Panjang yang dilakukan secarabersamaan di malam hari sebelum Tradisi Panjang Mulud di realisasikankeesokan harinya.

Sedangkan pada saat ini makna dari Tradisi Panjang Mulud, yaitu (Yadi Ahyadi, Komunikasi Pribadi, 11 Juni 2015): (1) Masyarakat dari golongan mampu maupun tidak mampu samasama berusaha untuk mengeluarkan dana semaksimal mungkin, untukmenyambut tradisi ini karena unsur ria atau sombong, (2) Bukan sebagai simbol kekuatan Islam lagi, karena yang diarak bukansimbol-simbol Islam melainkan simbol-simbol kehidupan. Simbol-simbolIslam yang adalah hadiah yang didapat dari Kerajaan Arab,seperti: bendera Nabi Ibrahim, Pedang Zulfikar, Kiswah, dan TiraiMakam Rasul. Sedangkan simbolsimbol kehidupan sepeti: berkat, nasi,telur, dan produk-produk instan.

Tradisi Panjang Mulud ini bukan hanya sebagai rasa euforia masyarakat Banten, namun ditengah-tegah rasa euforia masyarakat Banten tradisi ini juga dipengaruhi faktor keislaman. Jadi tradisi ini bukan hanya sebagai pengungkapan rasa gembira masyarakat Banten akan hadiah yang didapat dari Kerajaan Arab. Melainkan hadiah-hadiah yang di dapat itu memiliki nilai-nilai Islam yang kuatdan bulan dalam mengarak hadiah-hadiah itu di bulan Rabi'ul Awal.

Proses perubahan-perubahan yang terjadi dalam Tradisi Panjang Mulud ini, bukan semata-mata sebagai proses 
perubahan yang memberikan penyimpangan Tradisi Panjang Mulud. Perubahan makna yang terjadi bukan didasari atas faktorproses perubahanperubahan, melainkan dampak dari modernisasi yang menjadi faktor utama atas perubahan yang terjadi. Moderenisasi yang terjadi memberikan dampak sigifikanatas perubahan yang dilatar belakangi oleh pola pikir sampaigaya hidup modern.Gaya hidup yang cenderung instan, memberikan dampak terhadap sajiandalam Tradisi Panjang Mulud. Pada awalnya sajian yang diarak dalam tradisi ini berupa hadiah yang didapat dari kerajaan Arab. Namun untuk saat ini sajian yangdi arak tidak lagi sama dengan awal pelaksanaan Tradisi Panjang Mulud.

Dalam prespektif Cultural production atau produksi budaya, adalah sebuah ekspresi atau representasi yang diciptakan atau diasosiasikan dengan kelompok pada pengikat masyarakat dan atau komunitas. Produksi budaya umumnya muncul dari konteks historis khusus (Widiastuti, 2013). Tradisi Maulid tidak hanya sekedar untuk memperingati sejarah, bagi umat Muslim. Tetapi untuk mengenang sejarah Rasulullah, Tradisi Maulid dapat menjadi inspirasi paling sempurna bagi seorangMuslim dalam menjalankan apapun dalam realitas kehidupan seharihari (Nadia, 2011), karenaRasulullah, adalah sosok yang memberikan inspirasi yang sempurna bagi umat Muslim karena beliaulah agama Islam, menjadi satusatunya agama sempurna dimuka bumi ini. Dalam perayaan Maulid Nabi, masyarakat mengharapkan dapat menjadi pribadi seperti Rasulullah. Namun dalam realisasinya saat ini simbol-simbol yang menjadi ciri cenderung instan dan mudah didapat. Keinstanan yang terjadi bukan hanya semata-mata dari masyarakat, namun dilatarbelakangi oleh perubahan zaman yang cenderung instan.

Perkembangan zaman yang semakin modern, memberikan dampak terhadap pelaksanaan Tradisi Panjang Mulud di tengah-tengah masyarakat Banten. Awalnya Tradisi Panjang Mulud memiliki nilai gotong-royong, kebersamaan dan kekeluargaan, kini nilai-nilai itu berubah menjadi lebih individualis. Modernisasi menjadikan sesuatu hal manjadi lebih praktis tanpa memikirkan nilai-nilai luhur yang terkandung. Misalnya disaat awal Tradisi Panjang Mulud masyarakat akan membuat Panjang dan memberikan hasil bumi mereka dengan diolah dan dilakukan bersama-sama kini masyarakat lebih memilih membeli Panjang dan memberikan produkproduk instan untuk menghiasi Panjangnya karena beranggapan praktis dan lebih menghemat waktu. Akibat modernisasi itu juga masyarakat tidak lagi beranggapan adanya sedekah untuk lingkungan. Sedangkan dulu masyarakat akan bersedekah terhadap lingkungan untuk kelimpahan rezeki di kemudian hari, karena sifat masyarakat modern lebih cenderung bersifat dinamis atau selalu berubah mengikuti perkembangan zaman, akal pikiran manusia dan senantiasa mengembangkan efisiensi dan efektivitas, dan tidak mengandalkan atau 
mengutamakan kebiasaan atau tradisi masyarakat.

\section{KESIMPULAN}

Tradisi Panjang Mulud memiliki makna denotasi sebagai Tradisi yang menggambarkan kondisi rasa syukur dengan hadiah yang didapat oleh masyarakat Banten dari kerajaan Arab serta nilai ke-Islaman masyarakat Banten. Makna konotasi adalah rasa syukur atas hadiah yang didapatkan ini, memberikan rasa euforia masyarakat Banten dan selain itu bagi kalangan ulama masyarakat Banten juga mencurahkan rasa syukurnya dengan melakukan Dzikir Mulud dimana dalam dzikir ini, dilantunkan ayat-ayat Allah dengan lantunan lagu yang merdu. Tradisi ini menegaskan mitos, bahwa manusia harus mengkomunikasikan rasa syukurnya dengan merayakan hari-hari penting yang memiliki makna sejarah. Bukan hanya mengkomunikasikan kegembiraanya dengan sesama manusia saja. Namun, kita harus mengkomunikasikan kegembiraan kepada alam juga, supaya keselarasan dalam hidup terjalin dengan harmonis. Representasi dari Tradisi ini sebagai pengungkapan rasa kebahagiaan atas hadiah yang di dapat dari kerajaan Arab. Selain itu dari Tradisi Panjang Mulud ini, yang selalu diadakan setiap tahunnya memberikan rasa kebersamaan di antara sesama makhluk sosial. Bukan hanya makhluk sosial saja melainkan keselarasan dengan alam. Pada Tradisi Panjang Mulud ini, masyarakat berkesempatan untuk bersedekah.

\section{DAFTAR PUSTAKA}

Adeney-Risakotta, B. (2009). Is there a meaning in natural disasters? Constructionsofculture, religionandscience. Exchange, 38(3), 226-243.

Arif, S., \& Kusumaningratri, R. (2010). Refilosofi kebudayaan: Pergeseran pascastruktural. Ar-Ruzz Media.

Bramantyo, T. B. P. (2003). Konteks semiotika kesenian dalam kajian kebudayaan. Panitia Dies Natalis ISI.

Mardimin, Y. (1994). Jangan tangisi tradisi: Transformasi budaya menuju masyarakat Indonesia modern. Kanisius.

Nadia, Z. (2011). Tradisi maulid pada masyarakat Mlangi Yogyakarta. ESENSIA: Jurnal IlmuIlmuUshuluddin, 12(2), 367-384.

Pudjiastuti, T. (2007). Perang, dagang, persahabatan: Surat-surat Sultan Banten. Yayasan Obor Indonesia.

Rahmawati, A., Febriyanti, M., \&Nurrachmi, S. (2012). CulturalStudies: Analisis Kuasa Atas Kebudayaan. Jurnal Ilmu Komunikasi, 2(2).

Sobur, A. (2001). Analisis teks media: Suatu pengantar untuk analisis wacana, analisis semiotik dan analisis framing. Remaja Rosdakarya.

Widiastuti, T. T. (2013). CulturalProduction: Peran Media Pada Produksi Budaya Massa. Menggagas Pencitraan Berbasis Kearifan Lokal. 